\title{
PENINGKATAN PEMAHAMAN KONSEP DAN KOMPETENSI STRATEGIS MATEMATIS SISWA SMP DENGAN PENDEKATAN METAPHORICAL THINKING
}

Oleh:

\author{
M. Afrilianto \\ Program Studi Pendidikan Matematika, STKIP Siliwangi Bandung \\ afriliantomuhammad@yahoo.com
}

\begin{abstract}
Penelitian ini bertujuan untuk mendeskripsikan dan menelaah peningkatan pemahaman konsep dan kompetensi strategis matematis antara siswa yang memperoleh pembelajaran dengan pendekatan metaphorical thinking, dengan siswa yang memperoleh pembelajaran biasa. Jenis penelitian ini merupakan kuasi eksperimen. Populasi penelitian ini adalah seluruh siswa kelas VIII SMP Negeri 12 Bandung. Sampel dalam penelitian ini dipilih sebanyak 2 kelas dari kelas VIII. Kelas eksperimen memperoleh pembelajaran dengan pendekatan metaphorical thinking, dan kelas kontrol memperoleh pembelajaran biasa. Instrumen penelitian meliputi tes pemahaman konsep dan kompetensi strategis matematis, angket, pedoman observasi dan pedoman wawancara. Pengolahan data peningkatan pemahaman konsep dan kompetensi strategis matematis menggunakan uji-t dan uji MannWhitney. Hasil penelitian menunjukkan bahwa (1) Terdapat perbedaan peningkatan pemahaman konsep dan kompetensi strategis matematis antara siswa yang memperoleh pembelajaran dengan pendekatan metaphorical thinking, dengan siswa yang memperoleh pembelajaran biasa; (2) Siswa menunjukkan sikap yang positif terhadap pembelajaran dengan pendekatan metaphorical thinking.
\end{abstract}

Kata Kunci: pendekatan metaphorical thinking, pemahaman konsep matematis, kompetensi strategis matematis.

This research aim to describe and to analyze the enhancement of mathematical conceptual understanding and strategic competence between students in metaphorical thinking approach and conventional learning. This kind of research is a quasi experiment. The populations of this research are all of the students of VIII grade in SMP Negeri 12 Bandung. The samples of this research are by choosing 2 classes of VIII grade. The experiment class obtains the metaphorical thinking approach, and the control class obtains the conventional learning. The research of data is obtained by giving a mathematical conceptual understanding and strategic competence test, questionnaire, the observation directive, and the interview directive. The enhancement of mathematical conceptual understanding and strategic competence is processed by the t-test and Mann-Whitney test. The result of this research showed that (1) There is enhancement difference of mathematical conceptual understanding and strategic competence between students in metaphorical thinking approach and conventional learning; (2) Students showed positive attitude towards learning by metaphorical thinking approach.

Key words: metaphorical thinking approach, mathematical conceptual Understanding, mathematical strategic competence. 


\section{Pendahuluan}

\section{A. Latar Belakang}

Matematika merupakan salah satu disiplin ilmu dalam dunia pendidikan yang memegang peranan penting dalam perkembangan sains dan teknologi. Matematika juga bermanfaat dalam pengembangan berbagai bidang keilmuan yang lain. Dengan belajar matematika siswa dapat berlatih menggunakan pikirannya secara logis, analitis, sitematis, kritis dan kreatif serta memiliki kemampuan bekerjasama dalam menghadapi berbagai masalah serta mampu memanfaatkan informasi yang diterimanya. Untuk mengembangkan kompetensi tersebut, menurut TIM Kurikulum (2007:1) di dalam Kurikulum Tingkat Satuan Pendidikan (KTSP) yang sekarang diberlakukan, disusun standar kompetensi dan kompetensi dasar sebagai landasan pembelajaran matematika.

Proses pembelajaran merupakan suatu bentuk interaksi edukatif, yakni interaksi yang bernilai pendidikan yang dengan sadar meletakkan tujuan untuk mengubah tingkah laku dan perbuatan seseorang. Interaksi edukatif harus menggambarkan hubungan aktif dua arah antara guru dan anak didik dengan sejumlah pengetahuan sebagai mediumnya. Dalam interaksi edukatif unsur guru dan anak didik harus aktif, tidak mungkin terjadi proses interaksi edukatif bila hanya satu unsur yang aktif. Aktif dalam arti sikap, mental, dan perbuatan (Djamarah, 2000).

Selain itu, pada umumnya diindikasikan bahwa pembelajaran matematika kurang melibatkan aktivitas siswa secara optimal. Hal ini sesuai hasil studi Sumarmo (1993:55) terhadap siswa SMU, SLTP, dan guru di Kodya Bandung yang hasilnya antara lain pembelajaran matematika pada umumnya kurang melibatkan aktivitas siswa secara optimal sehingga siswa kurang aktif dalam belajar. Bahkan Wahyudin (1999:6) menegaskan bahwa guru matematika pada umumnya mengajar dengan metode ceramah dan ekspositori.

Pada beberapa tahun terakhir ini, pemahaman konsep dan kompetensi strategis banyak mendapat perhatian dari para pakar pendidikan. Apalagi setelah Mathematics Learning Study Committee, National Research Council (NRC), Amerika Serikat dalam publikasi bukunya yang berjudul Adding it Up: Helping Children Learn Mathematics pada tahun 2001 yang ditulis oleh Kilpatrick, Swafford, dan Findell, mengemukakan bahwa pemahaman konsep dan kompetensi strategis merupakan dua dari lima kecakapan matematis yang harus dikuasai siswa dalam pembelajaran matematika.

Menurut Kilpatrick, Swafford, \& Findell (2001:116), pemahaman konsep (conceptual understanding) adalah kemampuan dalam memahami konsep, operasi dan relasi dalam matematika. Berkaitan dengan pentingnya komponen pemahaman dalam matematika, Sumarmo (2002:2) juga menyatakan visi pengembangan pembelajaran matematika untuk memenuhi kebutuhan masa kini yaitu pembelajaran matematika perlu diarahkan untuk pemahaman konsep dan prinsip matematika yang 
kemudian diperlukan untuk menyelesaikan masalah matematika, masalah dalam disiplin ilmu lain dan masalah dalam kehidupan sehari-hari.

Masih menurut Kilpatrick, Swafford, \& Findell (2001:116), kompetensi strategis (strategic competence) merupakan suatu kemampuan untuk merumuskan, merepresentasikan, serta menyelesaikan permasalahan matematika.

Saat ini, pemahaman konsep dan kompetensi strategis matematis dinilai masih belum optimal dimiliki siswa. Sehubungan dengan masalah tersebut, diperlukan suatu pendekatan pembelajaran yang tepat untuk dapat meningkatkan pemahaman konsep dan kompetensi strategis matematis siswa. Salah satu pendekatan pembelajaran yang cukup relevan digunakan adalah pendekatan metaphorical thinking.

Menurut Carreira (2001:67), konsep berfikir yang menekankan pada kemampuan menghubungkan ide matematika dan fenomena yang ada diantaranya adalah metaphorical thinking.

Metaphorical thinking adalah proses berpikir yang menggunakan metafora-metafora untuk memahami suatu konsep. Menurut Holyoak \& Thagard (Hendriana, 2009:46), metafora bergerak dari suatu konsep yang diketahui siswa menuju konsep lain yang belum diketahui atau sedang dipelajari siswa.

Berdasarkan seluruh uraian di atas, terlihat bahwa pemahaman konsep dan kompetensi strategis matematis tersebut menentukan keberhasilan belajar matematika siswa. Penggunaan metaphorical thinking dalam proses belajar siswa menjadikan belajar siswa menjadi lebih bermakna (meaningful), karena siswa dapat melihat hubungan antara konsep yang dipelajarinya dengan konsep yang diketahuinya. Hal ini diharapkan dapat membuat siswa menyadari bahwa matematika bukanlah pelajaran yang sulit, tidak menarik dan membosankan, tetapi sebaliknya matematika merupakan pelajaran yang sangat menarik dan menyenangkan.

Oleh karena itu, peneliti melakukan penelitian mengenai peningkatan pemahaman konsep dan kompetensi strategis matematis siswa SMP dengan pendekatan metaphorical thinking. Selain itu, dari hasil penelitian ini juga diharapkan dapat dimanfaatkan oleh peneliti berikutnya yang tertarik meneliti lebih mendalam tentang bagaimana cara mengoptimalkan pemahaman konsep dan kompetensi strategis matematis siswa.

\section{B. Rumusan Masalah}

Berdasarkan latar belakang masalah yang telah diuraikan sebelumnya maka rumusan masalah dalam penelitian ini dapat diuraikan sebagai berikut:

1. Apakah terdapat perbedaan peningkatan pemahaman konsep matematis antara siswa yang memperoleh pembelajaran dengan pendekatan metaphorical thinking, dengan siswa yang memperoleh pembelajaran biasa? 
2. Apakah terdapat perbedaan peningkatan pemahaman konsep matematis antara siswa yang memperoleh pembelajaran dengan pendekatan metaphorical thinking, dengan siswa yang memperoleh pembelajaran biasa ditinjau dari kategori kemampuan matematis siswa?

3. Apakah terdapat perbedaan peningkatan kompetensi strategis matematis antara siswa yang memperoleh pembelajaran dengan pendekatan metaphorical thinking, dengan siswa yang memperoleh pembelajaran biasa?

4. Apakah terdapat perbedaan peningkatan kompetensi strategis matematis antara siswa yang memperoleh pembelajaran dengan pendekatan metaphorical thinking, dengan siswa yang memperoleh pembelajaran biasa ditinjau dari kategori kemampuan matematis siswa?

5. Bagaimana sikap siswa selama berlangsungnya pembelajaran dengan pendekatan metaphorical thinking?

\section{Tujuan Penelitian}

Berdasarkan latar belakang dan rumusan masalah yang telah dipaparkan di atas, maka tujuan penelitian ini adalah:

1. Untuk menelaah, mendeskripsikan, dan membandingkan kualitas peningkatan pemahaman konsep matematis antara siswa yang memperoleh pembelajaran melalui pendekatan metaphorical thinking dengan siswa yang memperoleh pembelajaran biasa.

2. Untuk menelaah, mendeskripsikan, dan membandingkan kualitas peningkatan pemahaman konsep matematis antara siswa yang memperoleh pembelajaran melalui pendekatan metaphorical thinking dengan siswa yang memperoleh pembelajaran biasa ditinjau dari kategori kemampuan matematis siswa.

3. Untuk menelaah, mendeskripsikan, dan membandingkan kualitas peningkatan kompetensi strategis matematis antara siswa yang memperoleh pembelajaran melalui pendekatan metaphorical thinking dengan siswa yang memperoleh pembelajaran biasa.

4. Untuk menelaah, mendeskripsikan, dan membandingkan kualitas peningkatan kompetensi strategis matematis antara siswa yang memperoleh pembelajaran melalui pendekatan metaphorical thinking dengan siswa yang memperoleh pembelajaran biasa ditinjau dari kategori kemampuan matematis siswa.

Untuk menelaah, mendeskripsikan sikap siswa selama berlangsungnya pembelajaran dengan pendekatan metaphorical thinking.

Matematika merupakan ilmu yang terstruktur dari axioma-axioma, definisi, teorema, lemma, corrolary. Begitu juga dengan permainan, terstruktur oleh aturan-aturan permainan. Rasa ingin tahu yang berawal dari pertanyaan apakah terdapat kesamaan antara algoritma dalam matematika dengan aturan yang dimiliki permainan telah mendorong untuk melakukan penelitian terhadap permainan itu sendiri. Dari beberapa permainan, permainan suit menjadi fokus awal penelitian karena suit biasa mengawali permainan-permainan yang lain. Setelah peneliti melakukan observasi 
awal terhadap permainan suit dihasilkan kesimpulan awal bahwa suit cenderung memiliki sifat siklis seperti dalam aljabar. Oleh karena itu dilakukan penelitian yang lebih mendalam terhadap suit ditinjau dari sudut pandang aljabar.

\section{Landasan Teori}

\section{A. Pendekatan Metaphorical Thinking}

Metaphorical thinking adalah proses berpikir yang menggunakan metafora-metafora untuk memahami suatu konsep. Menurut Holyoak \& Thagard (Hendriana, 2009:46), metafora bergerak dari suatu konsep yang diketahui siswa menuju konsep lain yang belum diketahui atau sedang dipelajari siswa.

Menurut Hendriana (2009:46), berpikir metaforik dalam matematika digunakan untuk memperjelas jalan pikiran seseorang yang dihubungkan dengan aktivitas matematiknya. Bentuk konseptual metafor meliputi:

a. Grounding methapors merupakan dasar untuk memahami ide-ide matematika yang dihubungkan dengan pengalaman sehari-hari.

b. Linking methapors : membangun keterkaitan antara dua hal yaitu memilih, menegaskan, membiarkan, dan mengorganisasikan karakteristik dari topik utama dengan didukung oleh topik tambahan dalam bentuk pernyataan-pernyataan metaforik.

c. Redefinitional methapors: Mendefinisikan kembali metafor-metafor tersebut dan memilih yang paling cocok dengan topik yang akan diajarkan.

\section{B. Pemahaman Konsep Matematis}

Salah satu kecakapan (proficiency) dalam matematika yang penting dimiliki oleh siswa adalah pemahaman konsep (conceptual understanding). Menurut Kilpatrick, Swafford, \& Findell (2001:116), pemahaman konsep (conceptual understanding) adalah kemampuan dalam memahami konsep, operasi dan relasi dalam matematika.

Adapun indikator dari pemahaman konsep matematis siswa adalah sebagai berikut:

a. Menyatakan ulang secara verbal konsep yang telah dipelajari.

b. Mengklasifikasikan objek-objek berdasarkan dipenuhi atau tidaknya persyaratan untuk membentuk konsep tersebut.

c. Menerapkan konsep secara algoritma.

d. Menyajikan konsep dalam berbagai macam bentuk representasi matematika.

e. Mengaitkan berbagai konsep (internal dan eksternal matematika).

(Kilpatrick, Swafford, \& Findell, 2001).

\section{Kompetensi Strategis Matematis}

Berdasarkan hasil penelitian dalam pembelajaran matematika, Kilpatrick, Swafford, \& Findell (2001:116) menyatakan bahwa kompetensi strategis (strategic 
competence) merupakan suatu kemampuan untuk merumuskan, merepresentasikan, serta menyelesaikan permasalahan matematika.

Adapun indikator dari kompetensi strategis matematis siswa adalah sebagai berikut:

a. Memahami situasi serta kondisi dari suatu permasalahan.

b. Menemukan kata-kata kunci serta mengabaikan hal-hal yang tidak relevan dari suatu permasalahan.

c. Menyajikan masalah secara matematik dalam berbagai bentuk.

d. Memilih penyajian yang cocok untuk membantu memecahkan permasalahan.

e. Menemukan hubungan matematik yang ada di dalam suatu masalah.

f. Memilih dan mengembangkan metode penyelesaian yang efektif dalam menyelesaikan suatu permasalahan.

g. Menemukan solusi dari permasalahan yang diberikan.

(Kilpatrick, Swafford, \& Findell, 2001).

\section{Metode Penelitian}

\section{Desain Penelitian}

Penelitian ini merupakan penelitian kuasi eksperimen. Pada kuasi eksperimen ini subjek tidak dikelompokkan secara acak, tetapi peneliti menerima keadaan subjek seadanya (Ruseffendi, 2005:52).

Desain pada penelitian ini yaitu desain kelompok kontrol non-ekivalen. Desain kelompok kontrol non-ekivalen tidak berbeda dengan desain kelompok pretes-postes, kecuali mengenai pengelompokan subjek. Pada desain kelompok kontrol nonekivalen subjek tidak dikelompokkan secara acak (Ruseffendi, 2005:52).

Desain penelitian ini berbentuk:

Kelas eksperimen

Kelas kontrol
O

$\mathrm{O}$
$\mathrm{X}$

(Ruseffendi, 2005:53).

Keterangan :

$\mathrm{O} \quad$ : Pretes dan postes (tes pemahaman konsep dan tes kompetensi strategis matematis).

X : Pembelajaran matematika dengan pendekatan metaphorical thinking.

\section{Subjek Penelitian}

Populasi penelitian ini adalah seluruh siswa kelas VIII SMP Negeri 12 Bandung tahun akademik 2011/2012. Sampel penelitian ini sebanyak dua kelas yaitu kelas VIII-E sebagai kelas eksperimen dan VIII-A sebagai kelas kontrol. 


\section{Variabel Penelitian}

Variabel bebas dalam penelitian ini adalah: (1) pendekatan metaphorical thinking (PMT) yang diberikan di kelas eksperimen; (2) pembelajaran biasa (PB) yang diberikan di kelas kontrol. Variabel terikat dalam penelitian ini adalah: (1) pemahaman konsep matematis siswa; (2) kompetensi strategis matematis siswa.

\section{Instrumen Penelitian}

Instrumen penelitian yang digunakan dalam penelitian ini terdiri dari lima jenis instrumen yaitu soal tes tertulis mengenai pemahaman konsep dan kompetensi strategis matematis yang dibuat dalam bentuk uraian, bahan ajar, angket skala sikap, pedoman observasi selama proses pembelajaran berlangsung dan pedoman wawancara.

\section{Teknik Pengumpulan Data}

Data dalam penelitian ini dikumpulkan melalui tes, lembar observasi, angket skala sikap dan lembar wawancara. Data yang berkaitan dengan pemahaman konsep dan kompetensi strategis matematis siswa dikumpulkan melalui tes (pretes dan postes). Selanjutnya, data yang berkaitan dengan sikap siswa dalam pembelajaran matematika dengan pendekatan metaphorical thinking dikumpulkan melalui angket skala sikap siswa.

\section{Teknik Analisis Data}

Sebelum data hasil penelitian diolah, terlebih dahulu dipersiapkan beberapa hal sebagai berikut:

a. Memberikan skor jawaban siswa sesuai dengan kunci jawaban dan sistem penskoran yang digunakan.

b. Menghitung Peningkatan kompetensi yang terjadi sebelum dan sesudah pembelajaran yang dihitung dengan rumus gain ternormalisasi (N-Gain), yaitu:

Gain ternormalisasi $(\mathrm{g})=\frac{\text { skorpostes }- \text { skorpretes }}{\text { skorideal }- \text { skorpretes }}($ Meltzer, 2002)

Hasil perhitungan gain kemudian diinterpretasikan dengan menggunakan klasifikasi sebagai berikut:

Tabel 1

Klasifikasi Gain (g)

\begin{tabular}{|c|c|}
\hline Besarnya Gain (g) & Interpretasi \\
\hline $\mathrm{g} \geq 0,7$ & Tinggi \\
\hline $0,3 \leq \mathrm{g}<0,7$ & Sedang \\
\hline $\mathrm{g}<0,3$ & Rendah \\
\hline & (Hake, 1999) \\
\hline
\end{tabular}


c. Menyajikan statistik deskriptif skor pretes, skor postes, dan skor N-Gain yang meliputi skor terendah $\left(X_{\text {min }}\right)$, skor tertinggi $\left(X_{\text {maks }}\right)$, rata-rata $(\bar{X})$, dan simpangan baku $(S)$.

d. Melakukan uji normalitas pada data pretes dan N-Gain pemahaman konsep dan kompetensi strategis matematis.

e. Menguji homogenitas varians data skor pretes dan N-Gain pemahaman konsep dan kompetensi strategis matematis.

\section{Hasil Penelitian dan Pembahasan}

\section{Deskripsi Hasil Pengolahan Data}

Data yang diolah dan dianalisis dalam penelitian ini meliputi skor pretes dan N-Gain dari pemahaman konsep dan kompetensi strategis matematis siswa kelas PMT dan kelas PB. N-Gain bertujuan untuk melihat mutu peningkatan pemahaman konsep dan kompetensi strategis matematis siswa setelah dilakukan pembelajaran. Peningkatan dimaksud adalah peningkatan secara keseluruhan dan peningkatan berdasarkan kategori kemampuan matematis siswa (tinggi, sedang, rendah).

\section{Tabel 2}

Statistik Deskriptif Skor Pemahaman Konsep Matematis

\begin{tabular}{|c|c|c|c|c|c|c|c|c|c|c|}
\hline \multirow{2}{*}{ Tes } & \multicolumn{9}{|c|}{ PB } & \multicolumn{7}{c|}{ PMT } \\
\cline { 2 - 12 } & $\boldsymbol{N}$ & $\boldsymbol{X}_{\min }$ & $\boldsymbol{X}_{\boldsymbol{m a k}}$ & & $\boldsymbol{S}$ & $\boldsymbol{N}$ & $\boldsymbol{X}_{\boldsymbol{m i n}}$ & $\boldsymbol{X}_{\boldsymbol{m a k s}}$ & $\ldots$ & $\boldsymbol{S}$ \\
\hline Pretes & 34 & 2 & 10 & 5,85 & 1,598 & 34 & 2 & 9 & 5,97 & 1,749 \\
\hline Postes & 34 & 5 & 17 & 12,18 & 2,758 & 34 & 12 & 24 & 18,7 & 3,947 \\
\hline N-Gain & 34 & 0,00 & 0,64 & 0,34 & 0,166 & 34 & 0,37 & 1,00 & 0,72 & 0,206 \\
\hline \multicolumn{10}{|c|}{ Skor Maksimal Ideal: 24} \\
\hline
\end{tabular}

Tabel 3

Statistik Deskriptif Skor Kompetensi Strategis Matematis

\begin{tabular}{|c|c|c|c|c|c|c|c|c|c|c|}
\hline \multirow[t]{2}{*}{ Tes } & \multicolumn{5}{|c|}{ PB } & \multicolumn{5}{|c|}{ PMT } \\
\hline & $N$ & $X_{\min }$ & $X_{\text {maks }}$ & th... & $S$ & $N$ & $X_{\min }$ & $X_{\text {maks }}$ & 8 & $S$ \\
\hline Pretes & 34 & 3 & 8 & 5,47 & 1,398 & 34 & 3 & 9 & 5,65 & 1,43 \\
\hline Postes & 34 & 8 & 15 & 11,68 & 2,142 & 34 & 12 & 28 & 23,21 & 4,92 \\
\hline N-Gain & 34 & 0,09 & 0,41 & 0,273 & 0,092 & 34 & 0,33 & 1,00 & 0,792 & 0,20 \\
\hline
\end{tabular}

Dalam penelitian ini peneliti juga menyajikan statistik deskriptif data skor pretes, postes dan N-Gain pemahaman konsep dan kompetensi strategis matematis berdasarkan kategori kemampuan matematis siswa. 
Tabel 4

Deskripsi Pemahaman Konsep Matematis Berdasarkan Kategori Kemampuan Matematis Siswa

\begin{tabular}{|c|c|c|c|c|c|c|c|}
\hline \multirow{2}{*}{$\begin{array}{c}\text { Data } \\
\text { Statistik }\end{array}$} & \multirow{2}{*}{$\begin{array}{c}\text { Kategori } \\
\text { Kemampuan } \\
\text { Matematis }\end{array}$} & \multicolumn{3}{|c|}{ PB } & \multicolumn{3}{|c|}{ PMT } \\
\hline & & Pretes & Postes & N-Gain & Pretes & Postes & N-Gain \\
\hline \multirow{3}{*}{ Rataan } & Tinggi & 6,67 & 12,67 & 0,344 & 7,89 & 21,67 & 0,857 \\
\hline & Sedang & 5,62 & 12,81 & 0,384 & 6,00 & 19,38 & 0,745 \\
\hline & Rendah & 5,44 & 10,56 & 0,265 & 4,00 & 14,78 & 0,534 \\
\hline \multirow{3}{*}{$\begin{array}{l}\text { Standar } \\
\text { Deviasi }\end{array}$} & Tinggi & 1,936 & 2,784 & 0,163 & 0,782 & 2,121 & 0,127 \\
\hline & Sedang & 1,455 & 2,073 & 0,134 & 1,155 & 3,667 & 0,204 \\
\hline & Rendah & 1,333 & 3,395 & 0,210 & 1,000 & 2,539 & 0,139 \\
\hline
\end{tabular}

Tabel 5

Deskripsi Kompetensi Strategis Matematis Berdasarkan Kategori Kemampuan Matematis Siswa

\begin{tabular}{|c|c|c|c|c|c|c|c|}
\hline \multirow{2}{*}{$\begin{array}{c}\text { Data } \\
\text { Statistik }\end{array}$} & \multirow{2}{*}{$\begin{array}{c}\text { Kategori } \\
\text { Kemampuan } \\
\text { Matematis }\end{array}$} & \multicolumn{3}{|c|}{ PB } & \multicolumn{3}{|c|}{ PMT } \\
\hline & & Pretes & Postes & N-Gain & Pretes & Postes & N-Gain \\
\hline \multirow{3}{*}{ Rataan } & Tinggi & 6,44 & 13,33 & 0,318 & 7,00 & 26,44 & 0,927 \\
\hline & Sedang & 5,31 & 11,31 & 0,261 & 5,44 & 23,88 & 0,821 \\
\hline & Rendah & 4,78 & 10,67 & 0,247 & 4,67 & 18,78 & 0,605 \\
\hline \multirow{3}{*}{$\begin{array}{l}\text { Standar } \\
\text { Deviasi }\end{array}$} & Tinggi & 1,130 & 2,000 & 0,081 & 1,000 & 2,128 & 0,096 \\
\hline & Sedang & 1,250 & 1,852 & 0,080 & 1,263 & 4,410 & 0,182 \\
\hline & Rendah & 1,481 & 2,000 & 0,114 & 1,118 & 4,944 & 0,206 \\
\hline
\end{tabular}

Tabel 6

Uji Perbedaan Rerata N-Gain Pemahaman Konsep Matematis Berdasarkan Kategori Kemampuan Matematis Siswa

\begin{tabular}{|c|c|c|c|}
\hline Asal Kelas Siswa & Pengujian & Signifikasi & Keterangan \\
\hline $\begin{array}{l}\text { Kategori Kemampuan } \\
\text { Matematis Tinggi }\end{array}$ & $\begin{array}{c}\text { Independent-Sample } T \\
\text { Test }\end{array}$ & 0,000 & Tolak $\mathrm{H}_{0}$ \\
\hline $\begin{array}{l}\text { Kategori Kemampuan } \\
\text { Matematis Sedang }\end{array}$ & Mann-Whitney U & 0,000 & Tolak $\mathrm{H}_{0}$ \\
\hline $\begin{array}{l}\text { Kategori Kemampuan } \\
\text { Matematis Rendah }\end{array}$ & $\begin{array}{c}\text { Independent-Sample } T \\
\text { Test }\end{array}$ & 0,006 & Tolak $\mathrm{H}_{0}$ \\
\hline
\end{tabular}

$\mathrm{H}_{0}$ : Peningkatan pemahaman konsep matematis tidak berbeda secara signifikan. 
Berdasarkan Tabel 6 di atas, maka dapat disimpulkan bahwa:

a. Pada kategori kemampuan matematis tinggi, $\mathrm{H}_{0}$ ditolak. Hal ini mengindikasikan bahwa terdapat perbedaan peningkatan pemahaman konsep matematis antara PMT dengan PB.

b. Pada kategori kemampuan matematis sedang, $\mathrm{H}_{0}$ ditolak. Hal ini mengindikasikan bahwa terdapat perbedaan peningkatan pemahaman konsep matematis antara PMT dengan PB.

c. Pada kategori kemampuan matematis rendah, $\mathrm{H}_{0}$ ditolak. Hal ini mengindikasikan bahwa terdapat perbedaan peningkatan pemahaman konsep matematis antara PMT dengan PB.

\section{Kesimpulan}

\section{Kesimpulan}

Berdasarkan hasil penelitian dan pembahasan mengenai perbedaan peningkatan pemahaman konsep dan kompetensi strategis matematis siswa, antara siswa yang memperoleh pembelajaran matematika dengan pendekatan metaphorical thinking, dengan siswa yang memperoleh pembelajaran biasa, diperoleh kesimpulan sebagai berikut:

1. Terdapat perbedaan peningkatan pemahaman konsep matematis antara siswa yang memperoleh pembelajaran dengan pendekatan metaphorical thinking, dengan siswa yang memperoleh pembelajaran biasa.

2. Terdapat perbedaan peningkatan pemahaman konsep matematis antara siswa yang memperoleh pembelajaran dengan pendekatan metaphorical thinking, dengan siswa yang memperoleh pembelajaran biasa ditinjau dari kategori kemampuan matematis siswa.

3. Terdapat perbedaan peningkatan kompetensi strategis matematis antara siswa yang memperoleh pembelajaran dengan pendekatan metaphorical thinking, dengan siswa yang memperoleh pembelajaran biasa.

4. Terdapat perbedaan peningkatan kompetensi strategis matematis antara siswa yang memperoleh pembelajaran dengan pendekatan metaphorical thinking, dengan siswa yang memperoleh pembelajaran biasa ditinjau dari kategori kemampuan matematis siswa.

5. Siswa menunjukkan respon yang positif terhadap pelajaran matematika, terhadap pembelajaran melalui pendekatan metaphorical thinking, serta terhadap soal-soal pemahaman konsep dan kompetensi strategis matematis.

\section{Saran}

Berdasarkan kesimpulan di atas, maka penulis mengemukakan beberapa saran sebagai berikut:

1. Bagi para guru matematika, pembelajaran melalui pendekatan metaphorical thinking hendaknya dijadikan sebagai salah satu alternatif pendekatan pembelajaran untuk diimplementasikan dalam pengembangan pembelajaran 
matematika di kelas, terutama untuk meningkatkan pemahaman konsep dan kompetensi strategis matematis siswa.

2. Perlu dikembangkan oleh pihak sekolah melalui Musyawarah Guru Mata Pelajaran (MGMP) Matematika, soal-soal untuk meningkatkan pemahaman konsep dan kompetensi strategis matematis siswa, agar siswa terbiasa mengerjakan soal-soal tersebut sehingga dapat meningkatkan pemahaman konsep dan kompetensi strategis matematis siswa.

3. Perlu dilakukan penelitian lanjutan, tetapi pada level sekolah tinggi atau rendah atau terhadap jenjang pendidikan lain seperti sekolah dasar, sekolah menengah atas, dan perguruan tinggi.

\section{DAFTAR PUSTAKA}

Carreira, S. (2001). Where There's a Model, There's a Metaphor: Metaphorical Thinking in Students' Understanding of a Mathematical Model. An International Journal Mathematical Thinking and Learning. 3(4), 261-287.

Djamarah, S.B. (2000). Guru dan Anak Didik dalam Interaksi Edukatif. Jakarta: Rineka Cipta.

Hake, R.R. (1999). Analyzing Change/Gain Scores. [Online]. Tersedia: http://www.physics.indiana.edu/sdi/Analyzingchange-Gain.pdf.[16 Januari 2012].

Hendriana, H. (2009). Pembelajaran dengan Metaphorical Thinking untuk Meningkatkan Kemampuan Pemahaman dan Komunikasi Matematik Siswa Sekolah Menengah Pertama. Disertasi. UPI: Tidak diterbitkan.

Kilpatrick, J., Swafford, J., \& Findell, B. (Eds.). (2001). Adding it Up: Helping Children Learn Mathematics. Washington, DC: National Academy Press.

Meltzer, D.E. (2002). The Relationship between Mathematics Preparation and Conceptual Learning Gains in Physics: a Possible "Hidden Variable" in Diagnostic Pretest Score. American Journal of Physics. Vol. 70 (12) 1259-1268.

Ruseffendi, E.T. (2005). Dasar-Dasar Penelitian Pendidikan \& Bidang Non-Eksakta Lainnya. Bandung: Tarsito.

Sumarmo, U. (1993). Peranan Kemampuan Logik dan Kegiatan Belajar terhadap Kemampuan Pemecahan Masalah Matematik pada Siswa SMA di Kodya Bandung. Laporan Penelitian IKIP Bandung: Tidak diterbitkan.

Sumarmo,U. (2002). Alternatif Pembelajaran Matematika dalam Menerapkan Kurikulum Berbasis Kompetensi. Makalah disajikan pada Seminar Nasional FPMIPA UPI: Tidak diterbitkan.

Tim KTSP. (2007). Kurikulum Tingkat Satuan Pendidikan. Jakarta: Depdiknas.

Wahyudin. (1999). Kemampuan Guru Matematika, Calon Guru Matematika, dan Siswa dalam Mata Pelajaran Matematika. Disertasi. UPI: Tidak diterbitkan. 